ていくのか、その考え方を明確にしておくべきときに到っ ている.

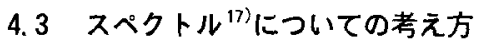

非化学的方法のうちです生物学的方法はごうしてもス ペクトルが狭いという問題があり、今迄のようにあらあ る付着生物を防止する必要はないとしても，優占種のみ を抑止した場合，次に優占種となったものによる被害が 許容範囲に収まるのかどうか, 制限防活 ${ }^{18)}$ についてよ

く検討することが必要である.

\section{4 電気化学的技術の探求}

細菌の電気制菌については既に成果が報告されてい $ろ^{19)}$ が，大型付着生物の生理作用等之電気化学的特性 との関係を探求すれば新しい対策の糸口之なる可能性が あろう。

\section{5 塩素処理の復活}

最す効果的でかつ経済的な技術である塩素処理法の復 活をはかることはできないのかを真剣に考えてみるべき ではなからうか。

\section{6 学際協力の推進}

生物学的方法の前途は洋々としているが，その実用化 までの途はけわしいと考えられ，それに向ってのなお一 層の学際協力の推進が望まれる.

\section{7 微生物誘導腐食の解明}

微生物誘導腐食も学際協力なしには全ぼうを解明する ことは困難であるが，学際協力をコーディネートするに は電気化学が最適任ということもできよう。

\section{文 献}

1）川辺允志，セミナークロリネーションの過去と現在予稿 集，海生想，11，(1986).

2）川辺允志，海生活損生物による障害と対策，海生想 (1988).
3）川辺允志，火力原子力発電，41，556(1990).

4) 相沢善吾，们丸豊彦，住谷吉男，大獄克彦，佐々木卓也， 今英樹，火力原子力発電，40，939(1989).

5）堀 正幸，永山王習，川辽允志，脇牧保大，山下桂司， シンポジウム無公害生物付着防止対策の動向予稿集, 海 生慜 133, (1990)

6) J.W.Whitehouse, M.Khalanski, M.G.Saroglia and H. A.Jenner, The Control of Biofouling in Marine and Fstuarine Power Stations, A Collaborative Research Working Group Report for use by Station Designers and Station Managers, CEGB, EDF, ENEL, KEMA, 1985 (海水抢上び间し水使用発䉓所における生物污摃対 策, 海生循, 1986)

7) A. Kawabe, K. Yasui, T. Ikeda, N. Nishijima, H. Yamamoto and A. Kawabe, Denki Kagaku 53, 422 (1985).

8）長谷良娧、山口敏明，シンポジウム無公㗉生物村着防江 対策の動向予稿集，海生䓡，118，(1990)。

9）洼田原長，シンポジウム無公書生物付着防止対策の動问 予稿集，海生愁，157，(1990)。

10）樑川正記，広由信義，網台地勝美，シンポジゥム哭公寒 生物付着防止対策の動问予稿集，海生懇，58，(1990)

11）加F隆介，海洋生物の付箐機構，85，恒星社愿生閣 (1991).

12) W.G.Characklis, M.J.Ninmons and B.F.Picologlou, $J$. Heal Transfer Eng., 3, 23 (1981).

13）川辺允志，火力原子力発電，41，703 (1990).

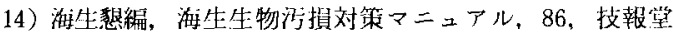
(1991).

15）海生賏偏，海生生物活損対策マニュアル，90，技報堂 (1991).

16)例えば, G.J.Licina, Source book for Microbiologically Influenced Corrosion in Nuclear Power Plants EPRI. (1988)

17）川过允志，火力原子力発電，41，556(1990).

18）梶原 武，海生生物による障害上対策，海生愁， 121 , (1992).

19）松永 是，ケミカル・エンジニアリング，1990，34 (1990).

\title{
有機エレクトロクロミック材料の新展開
}

\section{PED研究会 \\ 山本}

寛
現在，私たちの周辺には TVやコンピュータ端末をは じめとして数多くのディスプレイが氾監し，またその技 術の進歩には“目を見張る”ものがある。しかし，より 緻密で鮮明な高品位性，しかもコンパクトで扱い易い, まさに夢のようなディスプレイに対する要求はますます 百本大学埋工学部 (テ274 于葉県船橋市習志野台 7-24-1)
強くなりつつある。残念ながらこれに答える具体的な 表示方式や表示媒体については現在明確な候補があるわ けではなく,開発研究の劇的な進展が待だているのが 現状である。

さて，電気化学反応に伴う物質の色変化を利用する土 レクトロクロミック(EC)表示には，低い電压による色 
鮮やかな発色という大きな特徴があり，特異な応用分野 あ開拓されつつある1．しかし，上に述べたような次世 代のディスプレイの実現を考える時，EC 表示には越え ねばなら好幾つかの課題が指摘されている.

说来の $\mathrm{EC}$ 発色機構は，本質的には酸化還元反応に上 り，光吸収スペクトルが变化するところにある．その反 応には, 通常カチオンや電子の物質中への移動が伴い, 結果として色変化応答速度はゆっくりとしたものとなる. また，反応には明確なしきい值電圧が存在しないため， マトリクス表示用の駆動電子回路は複雑にならざるをえ なかった，さらに，電気化学反応の可逆性が $100 \%$ 保証 されなければ，発色くり返しによる少化も問題となる。

本文では，こうした課題を抜本的に解決する新しい夕 イプの EC 表示方式を目指し，著者らの提案している有 機多層膜を用いた新しい色变化機構の概念を紹介しつつ, 次世代のディスプレイへかける萝の一端を述べてみたい。

Bucher と Kuhn ${ }^{2)} 20$ 年以上前，色素の単分子膜を 形成し，これに強い電界を印加することによって生じる $\mathrm{EC}$ を報告している．色素分子軸に垂直な方向に印加さ れた電界の存在は，分子の励起状態の電子分布において 生じる分極エネルギーを低下させ，電界印加時の光吸収 スペクトルは低波長側ヘシフトすることになる。

報告された例では，色素分子はオクタデカンとのモル 比 $1: 1$ の混合単層膜中で安定に配列され, 強く電界に 耐えられるよう，分子はアラキジン酸カドミウム膜によっ てサンドイッチされている。 約 $5 \times 10^{8} \mathrm{~V} / \mathrm{m}$ の電界印加 により, $400 \mathrm{~nm}$ 付近で約 $5 \mathrm{~nm}$ の吸収スペクトル变化 が観察されている。

残念ながら，色変化量としては極めて小さい，しかし， 分子中での電子分布变化を考えれば理解できるように， 本質的にこの $\mathrm{EC}$ 応答速度は極めて大きい，現実的な $\mathrm{EC}$ 応答性は，むしろ薄膜素子のコンデンサ容量 $\mathrm{C}$ 上外 部駆動回路の抵抗 $\mathrm{R}$ で決まる時定数によって左右され るだろう。ちなみ，面積 $1 \mathrm{~cm}^{2}$, 比誘電率 2 程度の 1 $\mu \mathrm{m}$ 厚の膜素子を考えると, 駆動回路のインピーダン 又 $50 \Omega$ の時, 約 $10^{-6}$ 秒程度の応答性は期待できる。こ れは, 現在開発の進んでいる液晶の応答速度に比べても 2 桁以上速い。このモデルでは，はっきりとした色変化 をうるためには $10^{9} \sim 10^{10} \mathrm{~V} / \mathrm{m}$ 程度の強い電界が必要と なる，しかし，物質の耐絶縁電圧，あるいは駆動電圧な どを考虑すれば，そうした高電界を利用することは難し い．あちろん，分子分極の大きな材料を導入することに よって，既知の材料を利用してあスペクトル变化の点て 1 桁程度の向上は望めるかむしれない.しかしここでさ らに新しい EC 機構を考察することは意義深いといえる.

さて，有機系材料で一般に光吸収機構として知られて いる $\pi-\pi^{*}$ 遷移について考える。 $\pi$ 電子リングの分子 軌道に含まれる電子数が变化すれば，当然光吸収スペク
トルには大きな変化が生じる.これは酸化還元反応によ る通常の EC 反応において期待される現象である。一方, Fig.1に示されるように，高い対称性を示す $\pi$ 電子リン グに隣接して, 電任印加によって局所的分極場が誘起さ れれば， $\pi$ 電子リングに及ぼされる配位子場の対称性が 低下し，結果として縮退軌道は分裂する。これに伴い， 遷移エネルギーならびに光学的遷移確率は变化し, 吸収 スペクトルに大きな変化が生じることが期待される。

上記の機構を実現するより具体的な物質系として, 大 きな分極を有する薄膜と, $\pi$ - $\pi$ *発色性の EC 薄膜加 らなる多層膜界面が興味深い.Fig.2に著者らが検討し つつある， tーブチル - ルテチウムジフタロシアニン（EC

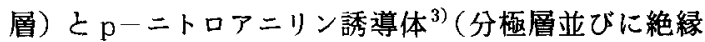
層)功る多層へテロ膜モデルを示す，界面において Fig. 1 に示した機構が作用すれば，フタロシアニンの 光吸収スペクトルは電圧印加によって変化することが期 待される. その応答速度はニトロアニリン分極の応答速 度によって決る，この時，常誘電的応答の場合，色変化 は印加される電界の強さにほぼ比例するであろうが，分 極層が仮に強誘電的に振舞えば，しきい値応答の可能性 すらある.

膜形成に用いられた LB 装置は垂直漫漬型で，へテロ 膜の作製に際しては $2 つ 0 \mathrm{LB}$ 累積装置を用意し，基板 ホルダーを逐次つけ替えて成膜した。フタロシアニンは 溶媒の揮発速度を考㢜し，メシチレンとの混合液とした。 また，ニトロアニリン誘導体は水面上分子膜の安定を計 るためアラキジン酸との混合物（モル比 $1: 1$ ）とし, 累積時には $\mathrm{CdCl}_{2}$ を水に溶解し，アラキジン酸を $\mathrm{Cd}$ 塩として膜を強化した ${ }^{3)}$. 得られたへテロLB 膜のX 線回折ダイアグラムによ机ば，へテロ膜界面はニトロア ニリンの分極基がフタロシアニンに隣接する構造を含ん でいることが確かめられだ、.

ITO 基板上に形成されたへテロ膜に対し，対向電極 に水銀を使用し電界応答を測定した。 $5 ， 10 ， 15 ， 20$ 工 ニットの試料を作製し，垂直方向の抵抗率，並びに絶縁

Nonpolarized state Polarized state

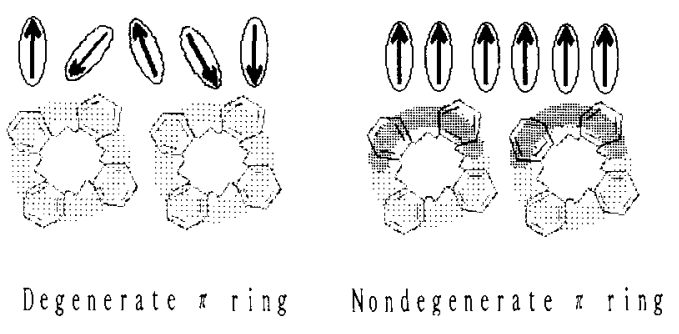

Fig. 1 Schematic concept of a newly proposed electrochromic system. 


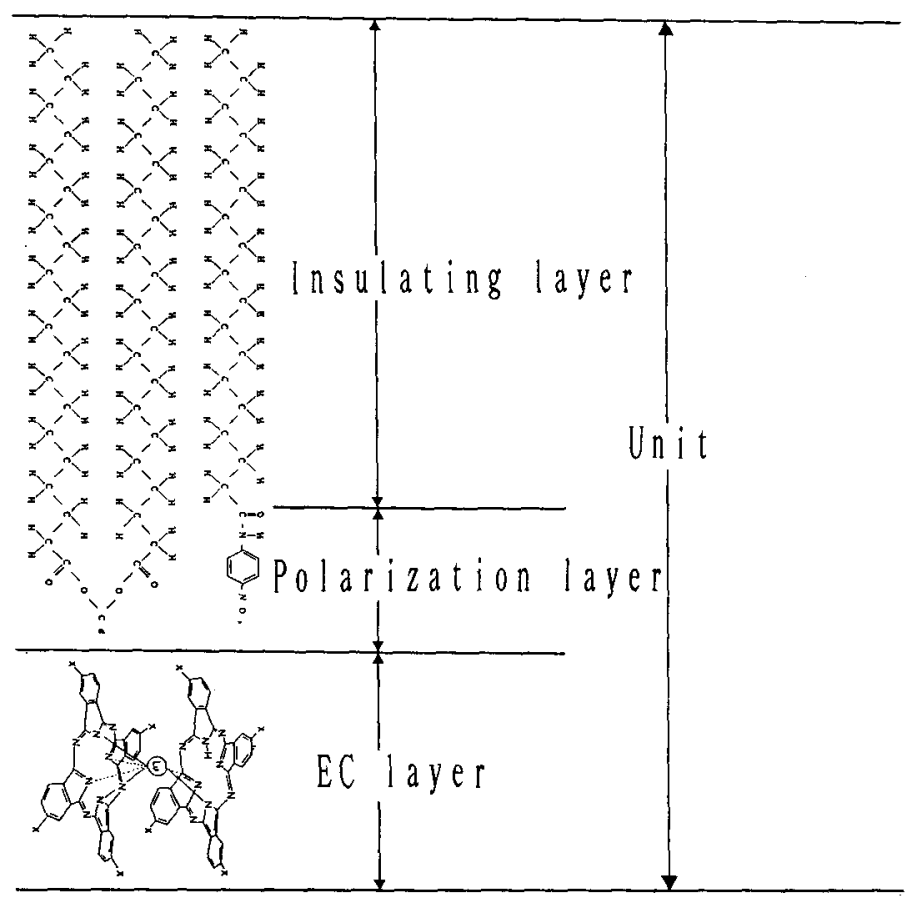

Fig. 2 Unit structure of multilayered LB film constructed with phthalocyanine and derivative of nitroaniline.

耐圧を測定した結果，それぞれ $\rho=3.4 \times 10^{5} \Omega ・ m$ (RT)， $5.0 \times 10^{7} \mathrm{~V} / \mathrm{m}$ であった，有機物の絶縁体であ るポリイミド系樹脂等と比べると抵抗率では数オーダ低 く, 絶縁耐圧は 1 オーダ低い ${ }^{5)}$.

光吸収スペクトルの電界応答測定系の精度は未だ十分 ではないが，10ユニット厚の試料を用いた実験では， 約 $1 \mathrm{~V}$ の電圧印加によって, $670 \mathrm{~nm}$ 付近のフタロシア ニンに特徴的な吸収ピークが变化するようである.

ここでは，マクロ的なイオンの移動を伴わない，新し いタイプの EC 機構の可能性と，有機超薄膜を用いた予 備的な実験の結果について簡単に紹介した。提案した表 示方式は, サブミリセコンドの超高速応答性, 単純な対 向電極式の低電压マトリクス駆動，ならびに超薄型の画 期的なディスプレイ媒体開発の可能性を与えてくれる. 現在, より明確な $\mathrm{EC}$ 特性の確認と, 機構解明を含めた
詳しい実験的検討を急いでいるが，関連する分野の皆さ んのご意見・批判等頂ければ幸いである。

\section{文 献}

1）馬場宣良，山名昌男，山本 寞編著，エレクトロクロミッ クディスプレイ，産業㘠書 (1991)。

2) H. Bucher and H. Kuhn, Z. Naturforsch, 25b, 1323 (1971).

3) Y. Miyamoto, K. Kaifu, M. Saito, M. Kato and K. Kawamura, Thin Solid Films, 178,493 (1989).

4）鎌田義彦，加藤 洋，二屉康好，柴田昌行，山本莧， 田中正一，電気化学秋季大会講演旨集 $(2 \mathrm{E} 08) ， 110$ (1991).

5）鎌田義彦，一户康好，柴田昌行，加藤洋一，山本 寛， 田中正:-，第39回応用物理関係連合講演会講演予稿集 No.3, (30p-n-7), 1074 (1992). 